\title{
Pengembangan Lembar Aktivitas SisWa Berbasis MaSAlah PADA MATERI GaRIS-GaRIS ISTIMEWA SEGITIGa DI KELAS VII SMP
}

\section{StUdENT ACTIVITY SHEET DEVELOPMENT BASED ON PROBLEM RELATED MATERIAL SPECIAL LINES TRIANGLE IN CLASS VII SMP}

\author{
Heny Sinaga ${ }^{1}$ Zulkardi $^{2}$ and M Yusup ${ }^{3}$ \\ ${ }^{1,2,3}$ Fakultas Keguruan dan Ilmu Pendidikan, Universitas Sriwijaya \\ Palembang, Sumatera Selatan, Indonesia \\ natalia.23jms@gmail.com
}

\begin{abstract}
Abstrak
Penelitian ini bertujuan untuk menghasilkan lembar aktivitas siswa berbasis masalah pada materi garis-garis istimewa segitiga di kelas VII SMP yang valid, praktis, dan memiliki efek potensial. Jenis penelitian ini adalah penelitian pengembangan dengan tahapan meliputi preliminary study dan tahapan formative evaluation (self evaluation, expert review, one-to one, small group, dan field test). Subyek penelitian dalam penelitian ini adalah kelas VII.8 di SMP Negeri 6 Palembang. Instrumen penelitian yang digunakan adalah lembar aktivitas siswa berbasis masalah, RPP, dokumen (lembar validasi), dan soal tes. Analisis data yang digunakan adalah analisis deskriptif. Pada tahapan expert review dan one-to-one dilakukan untuk melihat validitas lembar aktivitas siswa. Tahapan small group dilakukan untuk melihat kepraktisan. Adapun field test digunakan untuk melihat efek potensial dari lembar aktivitas siswa yang dikembangkan.
\end{abstract}

Kata Kunci: lembar aktivitas siswa, pengembangan, pembelajaran berbasis masalah, garis-garis istimewa segitiga.

\begin{abstract}
This study aims to produce a student activity sheet based on problem related material special lines triangle in class VII SMP which valid, practical, and have a potential effect. This type of research is development of research includes the preliminary study stages and phases of formative evaluation (self-evaluation, expert review, one-to-one, small group, and a field test). Research subjects in this study were VII.8 class in SMP Negeri 6 Palembang. Instruments used in this research is problem-based student activity sheets, lesson plans, documents (validation sheets), and test questions. Analysis of the data used is descriptive analysis. On the steps of expert reviews and one-to-one is made to see the validity of the student activity sheet. On the steps in small group made to look practicality. The field test is used to look at the potential effects of student activity sheets developed.
\end{abstract}

Keyword: student activity sheet, development, problem-based learning, special lines triangle.

\section{Pendahuluan}

Matematika adalah suatu ilmu dasar yang memegang peranan penting dalam perkembangan kehidupan manusia. Mata pelajaran matematika sangat penting diberikan kepada siswa dimulai dari tingkat pendidikan dasar yang digunakan untuk membekali setiap peserta didik dengan kemampuan berpikir logis, analitis, sistematis, kritis, dan kreatif, serta kemampuan bekerjasama. Kemampuan tersebut sangat diperlukan oleh setiap 
peserta didik untuk bertahan dalam persaingan secara global seiring dengan perkembangan zaman [1].

Salah satu materi matematika yang penting dan perlu dipahami oleh siswa adalah geometri dengan sub pokok bahasan adalah garis - garis istimewa segitiga. Perlunya mempelajari geometri diantaranya karena geometri membantu manusia memiliki apresiasi yang utuh tentang dunianya, eksplorasi geometri dapat membantu mengembangkan keterampilan pemecahan masalah, geometri memainkan peranan utama dalam bidang matematika lainnya, geometri banyak digunakan oleh banyak orang dalam kehidupan mereka sehari hari, dan geometri penuh teka - teki dan menyenangkan [2]. Hal ini berkaitan dengan Kurikulum Tingkat Satuan Pendidikan (KTSP), dimana melalui pembelajaran matematika diharapkan siswa Sekolah Menengah Pertama (SMP) mampu memahami bangun - bangun geometri, unsur - unsur dan sifat sifatnya, ukuran dan pengukurannya. Berdasarkan teori Van Hiele terdapat lima tahapan perkembangan kognitif yang dapat dicapai siswa dalam mempelajari geometri, yaitu tahap pengenalan, analisis, pengurutan, deduksi, dan keakuratan. Untuk mencapai setiap tahapan perkembangan kognitif tersebut, guru perlu mengajarkan materi geometri tersebut dengan lima fase, yaitu fase informasi, orientasi, penjelasan, orientasi bebas, dan integrasi. Dalam mengajarkan materi geometri ini, guru memerlukan bahan ajar yang dapat membantu dalam proses pembelajaran.
Berkaitan dengan Kurikulum Tingkat Satuan Pendidikan yang ditekankan pada Peraturan Menteri Pendidikan Nasional (Permendiknas) nomor 41 tahun 2007 tentang standar proses dimana dalam proses pembelajaran diperlukan perencanaan, pelaksanaan, penilaian, dan pengawasan proses pembelajaran untuk terlaksananya proses pembelajaran yang efektif dan efisien. Salah satu dari standar proses tersebut diperlukan perencanaan pembelajaran diantaranya dituangkan dalam Rencana Pelaksanaan Pembelajaran (RPP). Dalam mengembangkan Rencana Pelaksanaan Pembelajaran ini, guru juga perlu mengembangkan bahan ajar sebagai salah satu sumber belajar. Berbagai jenis bahan ajar dapat dikembangkan dan termasuk diantaranya pengembangan lembar aktivitas berbasis masalah.

Berdasarkan standar kompetensi untuk satuan pendidikan SMP, materi geometri mendapatkan porsi yang paling besar (41\%) dibandingkan dengan materi lain seperti aljabar (29\%), bilangan (18\%), serta statistika dan peluang (12\%). Menurut Clements bahwa siswa dapat mengenal lingkaran dan persegi tetapi tidak cukup bisa mengenal segitiga. Siswa tidak cukup mengenal segitiga dan melukisnya [3]. Selain itu, Widdiharto menyatakan bahwa pembelajaran matematika di SMP cenderung berorientasi pada buku teks, guru lebih mendominasi pembelajaran, dan materi matematika yang diajarkan kurang berkaitan dengan konteks dunia nyata siswa [4]. Kebanyakan guru dalam mengajar masih kurang memperhatikan kemampuan berpikir siswa atau dengan 
kata lain tidak mempertimbangkan tingkat kognitif siswa sesuai dengan perkembangan. Oleh karena itu, guru perlu mengembangkan bahan ajar berbasis masalah yang berkaitan konteks dunia nyata sehingga siswa berperan aktif dalam proses pembelajaran geometri.

Dalam rangka menuntun siswa memahami materi geometri sub pokok bahasan garis - garis istimewa segitiga, peneliti ingin mengembangkan lembar aktivitas siswa berbasis masalah pada materi tersebut. Menurut Daryanto dan Aris, lembar aktivitas siswa adalah lembar kegiatan yang memuat materi pelajaran yang harus dikuasai oleh siswa dan pelajaran juga disusun secara teratur langkah demi langkah sehingga dapat dengan mudah diikuti oleh siswa [5]. Manfaat dari penggunaan lembar aktivitas siswa, yaitu membantu siswa dalam mengembangkan konsep, melatih siswa untuk menemukan dan mengembangkan proses belajar mengajar, membantu siswa memperoleh catatan tentang materi yang dipelajari melalui langkah - langkah kegiatan pembelajaran, dan membantu siswa untuk menambah informasi tentang konsep yang dipelajari melalui kegiatan belajar secara sistematis. Hal ini sejalan dengan Kurikulum Tingkat Satuan Pendidikan (KTSP) bahwa pembelajaran matematika harus dimulai dengan pemberian masalah yang sesuai dengan situasi nyata dalam kehidupan sehingga siswa secara bertahap dibimbing untuk menguasai konsep matematika.

Kaitannya dengan pengembangan bahan ajar lembar aktivitas siswa berbasis masalah, terdapat penelitian oleh Pariska dengan judul "Pengembangan lembar kerja siswa berbasis masalah pada materi teorema phytagoras". [6] Pada penelitian pengembangan perangkat pembelajaran ini disimpulkan bahwa perangkat pembelajaran yang dikembangkan dikategorikan valid, praktis, dan efektif. Dalam penelitian tersebut, berdasarkan hasil wawancara yang dilakukan terhadap siswa tentang keefektifan diperoleh gambaran bahwa pembelajaran yang dilakukan guru lebih menarik dibandingkan dengan pembelajaran sebelumnya. Siswa berpendapat bahwa pada umumnya mereka menyukai pembelajaran seperti ini dan dapat mengetahui manfaat mempelajari materi tersebut dalam kehidupan sehari - hari.

Selain itu, terdapat penelitian dari Sugiarto yang berjudul "Pengembangan lembar kerja siswa berbasis aktivitas belajar pokok bahasan keliling dan luas bangun datar" dimana berdasarkan penelitian ini disimpulkan bahwa penguasaan siswa terhadap materi yang disajikan pada lembar kerja siswa dinyatakan baik, terbukti dari ketuntasan belajar siswa yang diperoleh sama dengan atau lebih dari Kriteria Ketuntasan Minimal (KKM) sebanyak 20 siswa dari 28 siswa [7]. Perbedaan penelitian ini dengan penelitian-penelitian sebelumnya adalah pada materinya dimana bahan ajar berupa lembar aktivitas siswa dibuat pada materi melukis garis-garis istimewa segitiga.

Dalam penelitian ini masalah yang dikaji adalah bagaimana karakteristik lembar aktivitas siswa berbasis masalah pada materi garis - garis istimewa segitiga 
di kelas VII yang valid, praktis, dan memiliki efek potensial terhadap hasil belajar siswa?

\section{Metode}

\section{A. Jenis Penelitian}

Penelitian ini merupakan penelitian pengembangan dengan tujuan untuk menghasilkan suatu produk bahan ajar berupa lembar aktivitas siswa berbasis masalah pada materi garis - garis istimewa segitiga di kelas VII.

\section{B. Subjek dan Tempat Penelitian}

Penelitian ini telah dilaksanakan di SMP Negeri 6 Palembang di kelas VII.8 semester ganjil yang siswanya berjumlah 39 orang.

\section{Prosedur Penelitian Pengembangan}

Penelitian ini terdiri dari dua tahap yaitu tahap preliminary (tahap persiapan dan tahap pengembangan materi) dan tahap formative study (tahap evaluasi dan tahap revisi). Adapun prosedur pengembangan lembar aktivtas siswa berbasis masalah sebagai berikut: ([8], [9])

\section{Preliminary}

Tahap ini meliputi :

a. Persiapan, tahap ini meliputi analisis materi dan kurikulum untuk menghasilkan lembar aktivitas siswa berbasis masalah yang tepat guna. Pada tahap ini juga peneliti menentukan subjek, sampel, dan jadwal penelitian.

b. Pendesainan, tahap ini meliputi pendesainan lembar aktivitas siswa berdasarkan pembelajaran berbasis masalah dan Kurikulum 2006 pada materi garis - garis istimewa segitiga.

\section{Formative study}

a. Self Evaluation, pada tahap ini, lembar aktivitas siswa berbasis masalah pada materi garis - garis istimewa segitiga yang telah didesain oleh peneliti akan dievaluasi sesuai dengan pembelajaran berbasis masalah dan Kurikulum 2006.

b. Prototyping, pada tahap ini, produk yang telah dibuat akan dievaluasi. Ada 3 kelompok uji coba dalam tahap ini sebagai berikut: 1) Expert Review dan One-To-One, hasil desain pada prototype pertama diberikan pada para pakar (expert review) dan seorang siswa (one-to-one). Expert Review berupa Walkthrough dimana untuk memperoleh lembar aktivitas siswa yang valid dan praktis maka digunakan pendapat para pakar. Para pakar memvalidasi lembar aktivitas siswa tersebut berdasarkan konten, konstruk, dan bahasa. Pada tahap one-to-one, peneliti mengujikan lembar aktivitas siswa tersebut pada siswa untuk melihat validnya lembar aktivitas siswa tersebut. Setelah peneliti merevisi lembar aktivitas siswa tersebut sesuai dengan pendapat pakar dan uji one to one, maka didapat propotype kedua. 2) Small Group (Kelompok Kecil), pada tahap ini, peneliti mengujikan prototype kedua tersebut pada kelompok kecil siswa kelas VII non subjek penelitian. Tahap ini bertujuan untuk melihat kepraktisan dan keefektifan dari prototype 2 serta untuk mengetahui kesulitan-kesulitan yang mungkin selama proses pembelajaran berlangsung, 3) Field Test (Uji Lapangan), pada tahapan ini uji coba 
dilakukan pada subjek penelitian yang sebenarnya sebagai field test. Lembar aktivitas siswa yang diujicobakan pada field test sudah memenuhi kriteria kualitas. Pada tahapan ini juga diberikan tes kepada siswa untuk melihat efek potensial dalam menjawab soal-soal yang ada.

\section{Teknik Pengumpulan Data dan Analisis Data}

Data yang diperoleh dikumpulkan menggunakan teknik pengumpulan data melalui dokumen, Walkthrough, observasi, dan tes. Adapun analisis data walkthrough berupa analisis lembar validasi dari para pakar. Hasil dari walkthrough yang telah diberikan oleh pakar dianalisis secara deskriptif sebagai masukan dan bahan untuk merevisi untuk perkembangan prototype. Data observasi berupa dokumentasi saat one-to-one, small group, dan field test terhadap prototype. Analisis data tes untuk mengukur kemampuan siswa dalam menjawab soal yang mengenai garis - garis istimewa segitiga dilakukan dengan cara menskor jawaban siswa menggunakan pedoman penskoran. Kemudian, nilai akhir siswa yang diperoleh dihitung.

Untuk menentukan banyaknya siswa yang mengalami keberhasilan diklasifikasikan menurut Kriteria Ketuntasan Minimal di SMP Negeri 6 Palembang yaitu 75. Selanjutnya menentukan kategori hasil belajar siswa disajikan pada Tabel 1.

Tabel 1. Kategori Hasil Belajar Siswa [10]

Nilai
$85-100$ Kategori Sangat Baik

\begin{tabular}{|cc|}
\hline $75-84$ & Baik \\
\hline $65-74$ & Cukup \\
\hline $45-64$ & Kurang \\
\hline $0-44$ & Sangat Kurang \\
\hline
\end{tabular}

III. Hasil dan Pembahasan

\section{A. Pengembangan Lembar Aktivitas Siswa}

Penelitian yang dilakukan adalah mengembangkan lembar aktivitas siswa berbasis masalah terhadap hasil belajar pada materi garis-garis istimewa segitiga di SMP Negeri 6 Palembang di kelas VII.8. Adapun tahap-tahap dalam pengembangan yang telah dilakukan dalam pengembangan ini adalah tahapan preliminary study dan tahapan formative evaluation (self evaluation, expert review, one-to one, small group, dan field test).

\section{Preliminary Study}

Sebelum mengembangkan suatu produk berupa lembar aktivitas siswa diperlukan analisis materi dan kurikulum. Kompetensi dasar yang akan dicapai pada penelitian ini adalah melukis garis tinggi, garis bagi sudut, garis berat, dan garis sumbu pada segitiga. Untuk mempelajari melukis garis-garis ini, siswa harus menguasai materi garis dan sudut. Selain itu, penetapan kelas penelitian juga dilakukan dan kelas VII.8 di SMP Negeri 6 Palembang sebagai subyek penelitian saat field test. Adapun desain perangkat pembelajaran terdiri dari desain lembar aktivitas siswa berdasarkan pembelajaran berbasis masalah dan kurikulum 2006. Selain itu, perangkat pembelajaran lainnya juga dibuat berupa RPP, lembar validasi, lembar observasi, dan soal tes. 


\section{Formative Evaluation}

Pada tahap formative evaluation ini, peneliti melakukan beberapa tahapan sebagai berikut.

a. Self Evaluation, peneliti mengevaluasi lembar aktivitas siswa sesuai dengan model pembelajaran berbasis masalah dan kurikulum 2006 untuk SMP dan dihasilkan lembar aktivitas siswa prototipe I

b. Expert Review dan One-to-One, pada tahap ini, prototipe I divalidasi oleh seorang pakar dan satu orang guru senior. Lembar aktivitas siswa divalidasi dari segi konten, konstruk, dan bahasa. Prototipe I yang telah dibuat diberikan kepada satu orang pakar, yaitu Dr.Ely Susanti, M.Pd. dan satu orang guru senior di Methodist 1 Palembang, yaitu P.Sihombing, S.Pd.

Seiring dengan tahap expert review dilakukan juga tahap one-to-one. Pada tahap ini, prototype I berupa lembar aktivitas siswa berbasis masalah diujikan pada dua orang siswa kelas VII SMP Negeri 51 Palembang yang bukan subyek penelitian bernama Rahel Aksana V.S. kelas VII.A dan Mega Mutiara kelas VII.E. Berdasarkan komentar dan saran para expert review dan one-to-one yang diberikan, maka prototipe I direvisi.

c. Small Group, prototype I yang telah direvisi menghasilkan prototype II. Prototipe II ini diujicobakan kepada kelompok siswa berjumlah tiga orang kelas VII SMP Negeri 51 Palembang yang bukan subyek penelitian. Pada tahap ini, siswa diminta mengerjakan lembar aktivitas siswa secara berkelompok. Pada saat pengerjaan lembar aktivitas siswa, peneliti meminta siswa memberikan saran dan komentar serta menjawab beberapa pertanyaan mengenai lembar aktivitas tersebut. Dari hasil uji coba pada small group, dalam mengerjakan soal, siswa perlu bimbingan dalam menyelesaikan setiap masalah dalam lembar aktivtas tersebut. Berdasarkan komentar dan saran siswa small group yang diberikan, maka prototipe II direvisi.

d. Field Test, setelah diperoleh prototype ketiga, maka dilakukan field test untuk melihat efek potensial lembar aktivitas siswa yang dikembangkan terhadap hasil belajar. Field test dilaksanakan pada tanggal 4-11 April 2015 di kelas VII.8 SMP Negeri 6 Palembang dengan jumlah siswa 39 orang. Siswa di dalam kelas tersebut dibagi menjadi 8 kelompok yang terdiri dari 4-5 siswa setiap kelompoknya. Kelompok dibentuk dengan ketua kelompok adalah siswa dengan nilai MID semester yang lulus KKM di sekolah tersebut sedangkan anggota kelompoknya dipilih oleh ketua kelompok tersebut. Pada saat field test, setiap kelompok diberikan lembar aktivitas berbasis masalah tersebut dan diselesaikan secara berkelompok. Hasil dari diskusi tersebut dipresentasikan oleh dua kelompok dan kelompok lain memberikan pendapatnya terhadap hasil diskusi kelompok tersebut. Berikut adalah tahap pelaksanaan field test pada pertemuan pertama dimana siswa diberikan lembar aktivitas siswa berbasis masalah dengan konteks layar 
perahu dan pembuatan kolam untuk melukis garis tinggi dan garis bagi sudut pada segitiga. Pada pertemuan kedua diberikan lembar aktivitas siswa dengan konteks membangun hotel dan mengangkat plat baja.

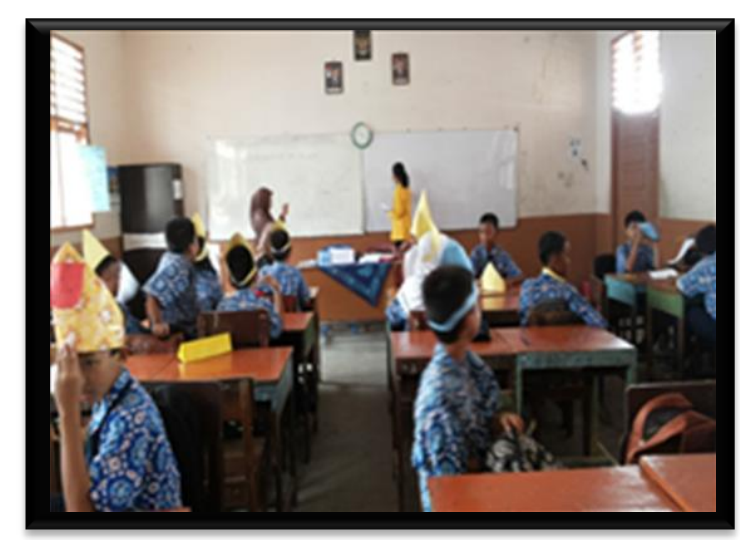

Gambar 1. Tahap Orientasi

Pada awal proses pembelajaran, peneliti memberikan penjelasan mengenai manfaat dan tujuan mempelajari materi garis-garis istimewa segitiga. Kemudian, peneliti melakukan apersepsi dengan memberikan beberapa pertanyaan mengenai garis dan sudut. Peneliti juga membagikan materi untuk belajar yang berisi pengertian dan langkah-langkah melukis garis-garis istimewa kepada siswa. Peneliti menjelaskan terlebih dahulu mengenai pengertian garis-garis istimewa pada segitiga tersebut. Selanjutnya, peneliti membagikan lembar aktivitas siswa berbasis masalah tersebut. Peneliti membimbing setiap kelompok mengenai langkah-langkah menyelesaikan masalah.

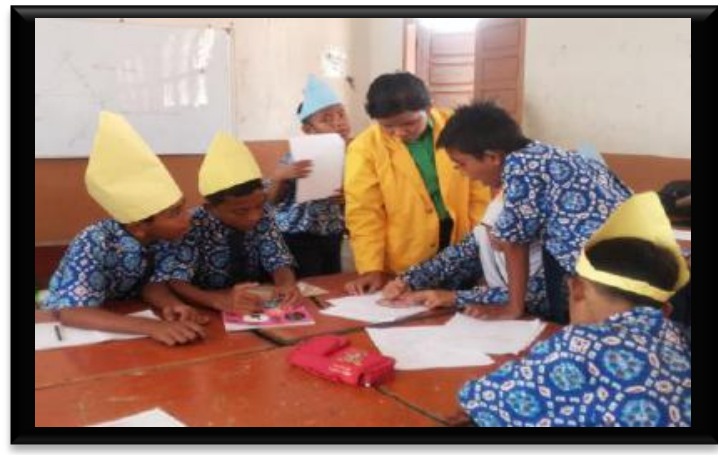

Gambar 2. Tahap Organisasi

Pada tahap oganisasi belajar ini, peneliti membantu siswa untuk memahami masalah dan langkah-langkah yang dimaksud pada masalah dalam lembar aktivitas tersebut. Siswa dalam kelompok berdiskusi untuk menyelesaikan masalah pada lembar aktivitas tersebut.

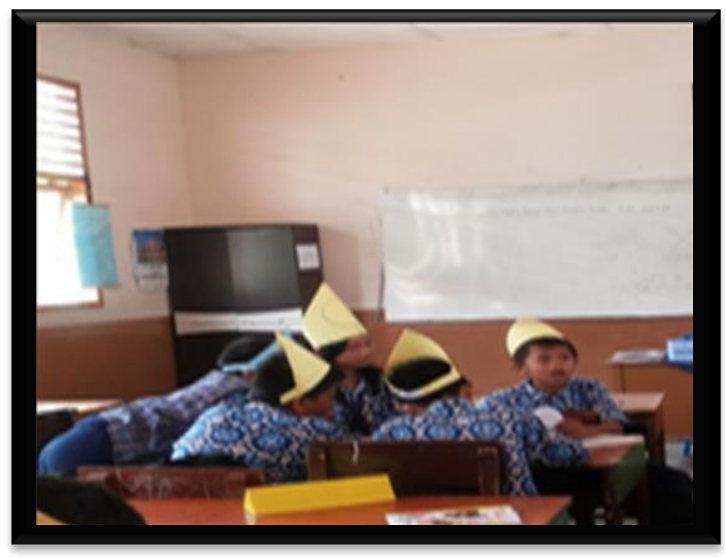

Gambar 3. Tahap Penyelidikan

Pada tahap ini, siswa mencari sumber belajar lain selain materi belajar yang diberikan tadi, baik melalui buku paket maupun sumber lainnya untuk menyelesaikan masalah pada lembar aktivitas tersebut. Berikut ini adalah contoh hasil jawaban salah satu kelompok mengenai masalah pertama tentang layar perahu yang terlihat pada gambar 4 . 


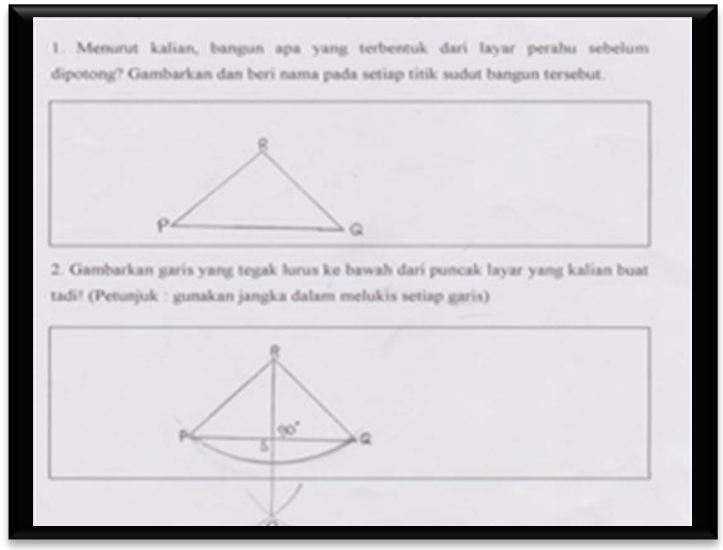

Gambar 4. Hasil Jawaban Siswa pada Masalah 1

Dari hasil jawaban yang dituliskan siswa, siswa dapat memodelkan bentuk layar perahu menjadi bentuk segitiga sama sisi. Ada sebagian kelompok yang hanya menggambar bangun segitiga sama sisi dan ada juga sebagian kelompok yang menuliskan juga nama bangunnya. Pada aktivitas di langkah kedua, kelompok dapat menentukan bahwa garis yang akan dilukis adalah garis tinggi. Kelompok tersebut sudah baik dalam melukis garis tinggi pada bangun yang telah dibuat pada aktivitas dilangkah kedua. Akan tetapi, kelompok tujuh memiliki jawaban berbeda dengan melukis garis tingginya tidak menggunakan jangka dan hanya mengikuti contoh gambar yang ada pada langkahlangkah melukis di materi belajar yang dibagikan pada awal pembelajaran. Hal itu dapat dilihat pada gambar 5 .

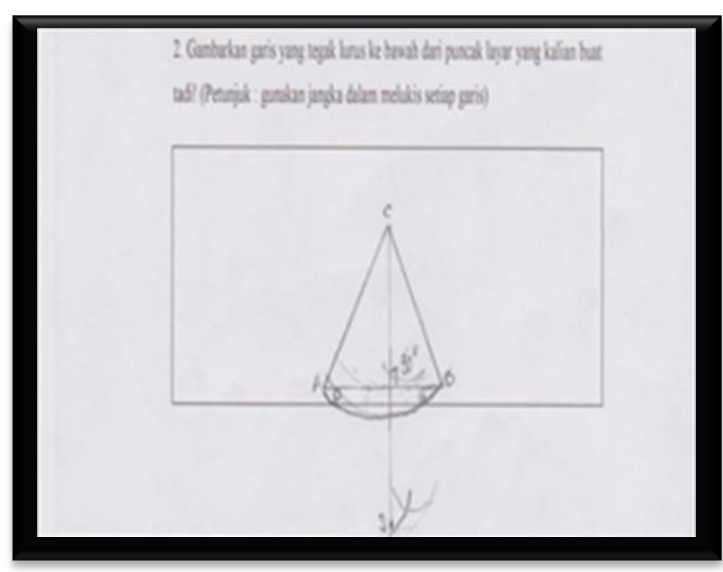

Gambar 5. Jawaban Kelompok Siswa di Langkah Kedua Masalah 1

Peneliti melihat bahwa kelompok tujuh dapat menyelidiki bahwa garis yang dilukis adalah garis tinggi. Namun, pada saat melukisnya, kelompok tujuh salah dalam menentukan titik potong dari busur lingkaran dengan ruas garis $\mathrm{AB}$. Kelompok tujuh menentukan titik potongnya adalah $\mathrm{P}$ dan $\mathrm{Q}$ tetapi bukan pada titik potong yang sebenarnya yang kelompok tersebut lukis. Hal ini juga terlihat pada jawaban kelompok lain yang juga mengalami kekeliruan pada saat menentukan titik potongnya. Ada juga kekeliruan lain dimana jari-jari lingkaran atau ukuran lebar jangka sering diubah sehingga pada saat melukisnya ukuran jangka pada busur pertama berbeda dengan busur kedua.

Setelah penyelidikan siswa mengembangkan dan menyajikan hasil penyelidikannya. Kelompok empat mempresentasikan masalah pertama dan kelompok lima mempresentasikan masalah kedua seperti pada gambar 6 . 


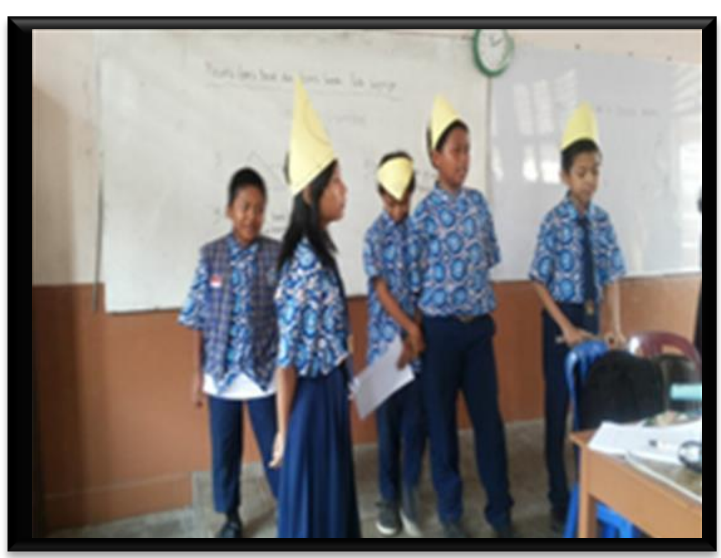

Gambar 6. Tahap Menyajikan Hasil Karya

Pada saat salah satu kelompok selesai mempresentasikan hasil penyelidikannya, kelompok lain juga diberikan kesempatan untuk menunjukkan hasil penyelidikan mereka dan memberi tanggapan untuk jawaban yang berbeda. Hal ini diperlukan untuk mengevaluasi hasil jawaban siswa mengenai masalah pada lembar aktivitas tersebut.

1) Analisis Data Dokumentasi Lembar Aktivitas Siswa Pertemuan I

Pertemuan pertama dilaksanakan pada tanggal 4 April 2015 yang dimulai pada pukul 07.30 WIB. Guru memulai pembelajaran dengan menyampaikan materi dan tujuan pembelajaran. Kemudian guru membagikan materi langkah-langkah melukis garis tinggi dan garis bagi sudut kepada setiap siswa. Guru menjelaskan terlebih dahulu mengenai pengertian dari garis tinggi dan garis bagi sudut sambil menanyakan beberapa pertanyaan mengenai titik sudut, sisi segitiga, dan jenis sudut. Selanjutnya, guru menyuruh siswa membentuk kelompok yang terdiri dari empat sampai lima orang. Terbentuklah delapan kelompok dengan ketua kelompok dipilih dari siswa dengan nilai ujian tengah semester diatas KKM.
Kemudian, guru membagikan lembar aktivitas siswa berbasis masalah dan memberi instruksi untuk menyelesaikan masalah mengenai garis tinggi dan garis bagi sudut dalam lembar aktivitas tersebut bersama teman kelompoknya. Setiap kelompok diberikan waktu kurang lebih tiga puluh menit untuk menyelesaikan masalah dalam lembar aktivitas tersebut. Lembar aktivitas tersebut telah dibuat dengan menggunakan karakteristik pembelajaran berbasis masalah sehingga dalam tahap pembelajarannya mengikuti langkah-langkah dalam pembelajaran berbasis masalah. Pada tahap pertama merupakan tahap orientasi dimana siswa mengenal materi garis tinggi dan garis bagi sudut, mengingatkan kembali mengenai materi prasyarat garis dan sudut, dan menyampaikan tujuan mempelajari materi ini kepada siswa. Kemudian pada tahap kedua merupakan tahap organisasi belajar dimana membantu siswa untuk memahami masalah dan kegiatan yang dimaksud pada langkah-langkah menyelesaikan masalah dalam lembar aktivitas tersebut. Siswa dalam kelompok berdiskusi untuk menyelesaikan masalah pada lembar aktivitas tersebut. Pada tahap ketiga, siswa mencari sumber belajar lainnya selain dari materi belajar yang diberikan untuk menyeldiki bagaimana melukis garis tinggi dan garis bagi sudut untuk menyelesaikan masalah tersebut. Pada tahap keempat, siswa mengembangkan dan menyajikan hasil penyelidikan mereka dan kelompok lain memberikan tanggapan mengenai hasil penyelidikan kelompok yang sedang mempresentasikan hasil jawaban mereka. 
Pada tahap terakhir, guru mengevaluasi hasil penyelidikan setiap kelompok kelompok dan menyimpulkan bersama tentang materi melukis garis tinggi dan garis bagi sudut.

Hasil jawaban siswa pada masalah pertama secara keseluruhan sekitar $89 \%$ jawaban siswa mendekati dengan jawaban yang diinginkan oleh peneliti. Hal ini menyatakan bahwa hampir sebagian kelompok mengerti maksud dari masalah dalam lembar aktivitas mengenai garis tinggi dalam kehidupan sehari-hari dan melakukan penyelidikan dengan baik mengenai setiap aktivitas pada langkahlangkah dalam lembar aktivitas tersebut. Meskipun pada saat pembelajaran siswa memerlukan bimbingan dalam langkahlangkah melukis garis tinggi tersebut karena masih banyak yang mengalami kekeliruan dalam menentukan titik potong dan keterampilan menentukan jari-jari busur lingkarannya.

Hasil jawaban siswa pada masalah kedua mengenai pembuatan kolam, secara keseluruhan $61 \%$ jawaban siswa mendekati jawaban yang sebenarnya yang diinginkan peneliti. Hal ini menyatakan bahwa kelompok siswa cukup mengerti tentang maksud soal tersebut. Dikategorikan cukup baik karena siswa cukup baik dalam mengikuti langkahlangkah pada penyelesaian masalah kedua. Kesalahan yang terjadi dalam penyelidikan adalah siswa mengalami kekeliruan dalam memperkirakan bentuk kolam yang akan dibuat dan garis yang akan dilukis.

Peneliti menyimpulkan berdasarkan hasil jawaban siswa pada lembar aktivitas tersebut bahwa sebagian besar kelompok sudah baik dalam mengerjakan langkahlangkah penyelesaian masalah dalam lembar aktivitas siswa tersebut hanya setiap siswa perlu latihan juga dirumah.

2) Analisis Data Dokumentasi dan Lembar Aktivitas Siswa Pertemuan II

Pertemuan kedua dilaksanakan pada tanggal 9 April 2015 yang dimulai pada pukul 10.00 WIB. Guru memulai pembelajaran dengan menyampaikan materi yang akan dipelajari tentang melukis garis berat dan garis sumbu seta tujuan mempelajarinya. Kemudian, guru menanyakan beberapa pertanyaan mengenai titik sudut, sisi segitiga, jenis sudut, dan mengenai materi garis. Selanjutnya, guru menyuruh siswa membentuk kelompok seperti pada pertemuan pertama. Guru membagikan materi tentang langkah-langkah melukis garis berat dan garis sumbu. Guru bersama siswa membahas pengertian garis berat dan garis sumbu. Kemudian, guru membagikan lembar aktivitas siswa berbasis masalah dan memberi instruksi untuk menyelesaikan masalah mengenai garis berat dan sumbu dalam lembar aktivitas tersebut bersama teman kelompoknya. Setiap kelompok diberikan waktu kurang lebih tiga puluh menit untuk menyelesaikan masalah dalam lembar aktivitas tersebut. Siswa sudah mulai terbiasa dengan lembar aktivitas tersebut sehingga siswa melakukan langkahlangkah dalam lembar aktivitas tersebut dengan baik. Setiap kelompok berdiskusi dan menanyakan kepada guru tentang halhal yang kurang dimengerti saat melukis garis berat dan garis sumbu. Kemudian, 
siswa mempresentasikan hasil penyelidikan mereka mengenai garis berat dan garis sumbu. Pada saat presentasi, kelompok lain memiliki jawaban yang berbeda dan guru mengevaluasi hasil jawaban kelompok tersebut. Perbedaannya pada garis yang dilukis pada masalah kedua. Kelompok yang mempresentasikan melukis garis sumbu dan kelompok lain melukis garis berat sehingga guru mengevaluasi hasil jawaban tersebut.

Hasil jawaban siswa pada masalah pertama mengenai posisi hotel secara keseluruhan sekitar $88 \%$ jawaban siswa mendekati dengan jawaban yang diinginkan oleh peneliti. Hal ini menyatakan bahwa kelompok siswa mengerti maksud dari masalah dalam lembar aktivitas mengenai garis sumbu dalam kehidupan sehari-hari dan melakukan setiap aktivitas pada langkahlangkah dalam lembar aktivitas tersebut. Meskipun siswa masih memerlukan bimbingan dalam melukis garis sumbu tersebut tersebut.

Hasil jawaban siswa pada masalah kedua mengenai plat baja, secara keseluruhan $78,75 \%$ jawaban siswa mendekati jawaban yang sebenarnya yang diinginkan peneliti. Hal ini menyatakan bahwa siswa dikategorikan baik untuk mengerti maksud masalah pada lembar aktivitas siswa tersebut. Siswa baik dalam mengikuti langkah-langkah pada penyelesaian masalah kedua. Meskipun dalam melakukan penyelidikan, ada beberapa kelompok yang hanya melukis sampai garis sumbu saja dan tidak melanjutkan ke melukis garis beratnya.
Peneliti menyimpulkan berdasarkan hasil jawaban siswa pada lembar aktivitas tersebut bahwa sebagian besar kelompok sudah baik dalam mengerjakan setiap masalah mengenai melukis garis berat dan garis sumbu pada segitiga dengan tambahan setiap siswa perlu latihan juga sendiri di rumah.

\section{B. Efek Potensial dari Lembar Aktivitas Siswa Berbasis Masalah terhadap Hasil Belajar}

Berdasarkan hasil field test yang telah dilakukan, diperoleh bahwa lembar aktivitas siswa berbasis masalah yang telah diujicobakan di SMP Negari 6 Palembang menghasilkan lembar aktivitas siswa yang mempunyai efek potensial. Hal ini ditunjukkan pada hasil jawaban siswa pada lembar aktivitas siswa berbaasis masalah selama dua pertemuan.

Berdasarkan hasil analisis jawaban siswa pada lembar aktivitas siswa berbasis masalah didapat bahwa jawaban siswa sudah mengarah pada jawaban sebenarnya yang diinginkan. Hampir sebagian kelompok siswa dapat mengerjakan setiap langkah dengan benar. Terdapat enam kelompok dengan kategori baik dan sangat baik dalam mengerjakan lembar aktivtas tersebut. Namun, terdapat dua kelompok dengan kategori cukup. Hal ini dikarenakan, pada saat melukis garisnya, terdapat kelompok yang melukisnya kurang tepat sesuai dengan langkahlangkah melukis yang diberikan pada materi belajar sehingga perlu bimbingan dalam melukisnya. Adapun hasil analisis jawaban siswa terhadap lembar aktivitas siswa tersebut ditunjukkan pada tabel 2. 
Tabel 2.

Hasil Analisis Lembar Aktivitas Siswa Pada Materi Garis-Garis Istimewa Segitiga

\begin{tabular}{|llllll|}
\hline No & Klpk. & $\begin{array}{c}\text { LAS } \\
\mathbf{1}\end{array}$ & $\begin{array}{c}\text { LAS } \\
\mathbf{2}\end{array}$ & $\begin{array}{c}\text { Rata- } \\
\text { rata }\end{array}$ & Kriteria \\
\hline 1 & I & 76 & 100 & 88 & Sangat baik \\
\hline 2 & II & 80 & 72 & 76 & Baik \\
\hline 3 & III & 78 & 84 & 81 & Baik \\
\hline 4 & IV & 78 & 92 & 85 & Sangat baik \\
\hline 5 & V & 76 & 82 & 79 & Baik \\
\hline 6 & VI & 76 & 88 & 82 & Baik \\
\hline 7 & VII & 58 & 78 & 68 & Cukup \\
\hline 8 & VIII & 66 & 80 & 73 & Cukup \\
\hline
\end{tabular}

\section{Penutup}

Berdasarkan hasil penelitian di SMP Negeri 6 Palembang dapat disimpulkan sebagai berikut:

1. Bahan ajar berupa lembar aktivitas siswa yang dikembangkan dengan pendekatan pembelajaran berbasis masalah dikatakan valid dan praktis.

2. Penelitian ini juga menghasilkan lembar aktivitas siswa yang memiliki efek potensial terhadap hasil belajar siswa SMP Negeri 6 Palembang pada materi garis-garis istimewa segitiga.

\section{Daftar Pustaka}

[1] Depdiknas. Peraturan Menteri No.22 Tentang Standar Kompetensi dan Kompetensi Dasar, Jakarta:Depdiknas, 2006

[2] Walle, (2015, Maret), Geometric Thinking and Geometric Concepts, http://www.google.co.id/url?sa=t\&rct $=\mathrm{j} \& \mathrm{q}=\& \mathrm{esrc}=\mathrm{s} \&$ source $=\mathrm{web} \& \mathrm{~cd}=1 \&$ cad $=$ rja\&uact $=8 \& v e d=0 \mathrm{CBwQFjAA}$ \&url=http $\% 3 \mathrm{~A} \% 2 \mathrm{~F} \% 2 \mathrm{Ftian}$. terc.edu \%2Fempower_readings $\% 2 \mathrm{Fvan} \% 252$ 0de $\% 2520$ walle.pdf\&ei $=$ Ln44Vb7QA oGdugTgo4GYBg\&usg=AFQjCNGY PziOGSCINroL3pSuTFES9ThmRw.
[3] Douglas H. Clements, (2015, Maret), Teaching and Learning Geometry, https://www.google.co.id/url?sa=t\&rct $=\mathrm{j} \& \mathrm{q}=\&$ esrc $=\mathrm{s} \&$ source $=\mathrm{web} \& \mathrm{~cd}=1 \&$ $\underline{\mathrm{cad}}=\mathrm{rja} \&$ uact $=8 \& \mathrm{ved}=0 \mathrm{CB} 8 \mathrm{QFjAA} \&$ url=https $\% 3 \mathrm{~A} \% 2 \mathrm{~F} \% 2$ Fmoodle.educat ion.wisc.edu\%2Fpluginfile.php $\% 2 \mathrm{~F} 87$ 73\%2Fmod_resource $\% 2 \mathrm{Fcontent} \% 2 \mathrm{~F}$ $\underline{0 \% 2 \mathrm{FV} a n \_H i e l e \_m o d e l \_r e a d i n g s} \% 2$ FClements_2003.pdf\&ei=ioI4VabnBI eugSDp4HQBQ\&usg=AFQjCNFOps h91Ihs_acMrsCPEDkih8pKeg.

[4] Rachmadi Widdiharto, Diagnosis Kesulitan Belajar Matematika SMP dan Alternatif Remidinya, Yogyakarta: Departemen Pendidikan Nasional, 2008.

[5] Daryanto dan Aris Dwicahyono, Pengembangan Perangkat Pembelajaran (Silabus, RPP, PHB, Bahan Ajar), Yogyakarta:Gava Media, 2014.

[6] Pariska, dkk, "Pengembangan Lembar Kerja Siswa Matematika Berbasis Masalah", Jurnal Pendidikan Matematika, Volume 1, No. 1, 2012.

[7] Sugiarti, Nani, Bambang Priyo Darminto, dan Riawan Yudi Purwoko, 2013.

[8] Tessmer, Planning and Conducting Formative Evaluations, Londen:Kogen Page, 1993.

[9] Zulkardi, (April, 2015), Developing A Learning Environment On Realistic Mathematics Education For Indonesian Student Teachers, (Online), Disertasi.

[10] Suharsimi Arikunto, Dasar-dasar Evaluasi Pendidikan, Jakarta: Bumi Aksara, 2009. 